\title{
Conventional and organic cropping systems at Suitia I: Experimental design and summaries
}

\author{
ASKO O. HANNUKKALA, ${ }^{1}$ JUKKA KORVA $^{2}$ and EEVA TAPIO ${ }^{3}$ \\ ${ }^{1}$ Institute of Plant Protection, Agricultural Research Centre \\ SF-31600 Jokioinen, Finland \\ ${ }^{2}$ Department of Plant Husbandry, University of Helsinki \\ SF-00710 Helsinki, Finland \\ ${ }^{3}$ Department of Plant Pathology, University of Helsinki \\ SF-00710 Helsinki, Finland
}

\begin{abstract}
The effects of four conventional and four organic cropping systems on the crop yield and yield quality, on the microbial activity of soil, on weeds, plant diseases, insect pests and earthworms were compared in a field experiment on the Suitia Experimental Farm in Southern Finland in 1982-1988. In the conventional cropping systems, industrial fertilisers and chemical pesticides were used according to practices adopted on actual farms in Southern Finland. In the organic cropping systems, plant nutrition was based on biological $\mathrm{N}$ fixation by legumes and organic manures. No chemical pesticides were used.

The average yield of barley in organic cropping varied between one quarter and half of that in conventional cropping. The yields of winter wheat, oats and potato were about $40 \%$ of those obtained conventionally. The yields of clover-grass leys in organic farming were similar to those of grass-leys in the conventional system. Unfortunately, the clover-grass leys outwintered after the first year.

The primary reason for the poor crop growth in the organic cropping systems was apparently the acute $\mathrm{N}$ deficiency caused by poor performance of legumes, low $\mathrm{N}$ content of organic manures and $\mathrm{N}$ losses in anaerobic conditions often occurring during winter and early spring. Pronounced soil compaction and anaerobic conditions in organic cropping systems had a harmful effect on the microbiological activity of soil as well as on earthworms. Weeds, plant diseases and insects were not a remarkable problem in any of the cropping systems.
\end{abstract}

Index words: Arable cropping systems, organic farming, extensive farming, crop sequence, rotation, fertilisers, pesticides, Hordeum vulgare, Triticum aestivum, Avena sativa, Solanum tuberosum, Trifolium, Vicia 


\section{Introduction}

The chemicalised agriculture practised in the industrial world has aroused criticism against the way food and feedstuffs are produced. On the background there is the concern of the effects of agricultural chemicals on the environment and on the health of consumers and farmers. Recently, organic farming systems, where the use of industrial fertilisers and chemical pesticides is reduced or forbidden, have gained popularity.

There is a wide range of cropping practices that can be classified as organic. The aim of this study was to evaluate crop growth, soil properties and the occurrence of pests in certain cropping systems managed according to organic principles as opposed to cropping systems managed by conventional methods. The organic systems in this study mostly follow the guidelines of the International Federation of Organic Agriculture Movements (IFOAM). However, they are not suggested to be representative of the numerous different organic systems followed on actual farms in Finland.

This paper presents the experimental design and a short review of results. The effects of the cropping system on the crop yield and yield quality (KorVA and VARIS 1990), on the microbial activity of soil (HEINONEN-TANSKI 1990), on weeds (KAUPPILA 1990), plant diseases (HANNUKKala and TAPIO 1990), insect pests (Helenius 1990) and earthworms (NuU. TINEN and HAUKKA 1990) are discussed in separate papers in this issue.

\section{Material and methods}

\section{Cropping systems}

Four conventional cropping systems and four organic cropping systems were compared in a field experiment. All cropping systems were based on a six year crop sequence. Traditional field experimental techniques were applied with the exception that the plot size allowed the use of farm-scale machinery. The intention was to compare the cropping systems as a whole rather than individual factors affecting the systems. The best management practices available were applied in both the conventional and the organic systems. However, the information available on organic cropping was often controversial. Consequently, several changes in cropping practices had to be made during the experiment to avoid complete destruction of the organic systems.

In the conventional cropping systems, fertilisation was based on industrial fertilisers used according to present recommendations to meet the need of the crop under cultivation. Pesticides were used as necessary. Three of the systems represented crop sequences suitable for plant production. The fourth represented a cropping system followed on a conventional cattle farm, where slurry was used in addition to industrial fertilisers (Table 1). The codes and names of the conventional cropping systems used in the text are as follows:
A1 = barley monoculture
A2 $=$ cereal production
A $3=$ diverse plant production
$\mathrm{B}=$ cattle farm

In the organic cropping systems, virtually no industrial fertilisers and pesticides were allowed. Two cropping systems for plant production and two for a cattle farm were established. In plant production systems plant nutrition was based on catch crops and green manuring with legumes. In cattle farm systems, farm yard manure (FYM) was applied additionally. For practical reasons, FYM had to be replaced by slurry mixed with straw and peat,

The two plant production systems followed the same crop sequence. This was also the case in the two cattle farm systems. The difference between the plant production and cattle farm systems was in the use of composts; all organic and inorganic material used as manure was either composted or the same ingredients were incorporated in the soil without composting (Table 1). The codes and 
Table 1. Crop sequences and crops in conventional and organic cropping systems in 1982-1988.

\begin{tabular}{|c|c|c|c|c|c|c|c|}
\hline \multirow{2}{*}{$\begin{array}{l}\text { Year } \\
\text { Phase a }\end{array}$} & \multirow[b]{2}{*}{ Phase b } & \multicolumn{4}{|c|}{$\begin{array}{l}\text { Cropping system } \\
\text { Conventional }\end{array}$} & \multirow{2}{*}{$\begin{array}{l}\text { Organic } \\
\mathrm{C} 1 / \mathrm{C} 2\end{array}$} & \multirow[b]{2}{*}{ D1/D2 } \\
\hline & & Al & $\mathrm{A} 2$ & A3 & B & & \\
\hline 1982 & 1982 & barley & barley & barley & $\begin{array}{l}\text { barley + } \\
\text { ley }\end{array}$ & $\begin{array}{l}\text { barley + } \\
\text { clover }\end{array}$ & $\begin{array}{l}\text { barley }+ \\
\text { ley }\end{array}$ \\
\hline 1983 & 1986 & barley & oats & $\begin{array}{l}\text { oats }+ \\
\text { bean' }\end{array}$ & $\begin{array}{l}\text { grass } \\
\text { ley }\end{array}$ & $\begin{array}{l}\text { barley + } \\
\text { clover }\end{array}$ & ley \\
\hline 1984 & 1987 & barley & $\begin{array}{l}\text { spring } \\
\text { wheat }\end{array}$ & potato & $\begin{array}{l}\text { grass } \\
\text { ley }\end{array}$ & potato & ley ${ }^{3}$ \\
\hline 1985 & 1988 & barley & barley & barley & $\begin{array}{l}\text { grass } \\
\text { ley }\end{array}$ & $\begin{array}{l}\text { green } \\
\text { manure } 2\end{array}$ & ley $y^{4}$ \\
\hline 1986 & 1983 & barley & $\begin{array}{l}\text { winter } \\
\text { wheat }\end{array}$ & $\begin{array}{l}\text { winter } \\
\text { wheat }\end{array}$ & $\begin{array}{l}\text { winter } \\
\text { wheat }\end{array}$ & $\begin{array}{l}\text { winter } \\
\text { wheat }\end{array}$ & $\begin{array}{l}\text { winter } \\
\text { wheat }\end{array}$ \\
\hline 1987 & 1984 & barley & barley & $\begin{array}{l}\text { turnp } \\
\text { rape }\end{array}$ & oats & $\begin{array}{l}\text { oats }+ \\
\text { bean' }\end{array}$ & $\begin{array}{l}\text { oats } \\
\text { bean' }\end{array}$ \\
\hline 1988 & 1985 & barley & barley & barley & $\begin{array}{l}\text { barley + } \\
\text { ley }\end{array}$ & $\begin{array}{l}\text { barley }+ \\
\text { clover }\end{array}$ & $\begin{array}{l}\text { barley + } \\
\text { ley }\end{array}$ \\
\hline
\end{tabular}

\footnotetext{
1 Vicia faba

2 In 1985 Persian clover, in 1988 a mixture of Vicia villosa, oats, Persian clover and Italian ryegras

${ }^{3}$ in 1984 Persian clover

4 in 1985 Persian clover, in 1988 the same mixture as green manure in $\mathrm{C} 1$
}

names of the organic cropping systems used in the text are as follows:

$$
\begin{aligned}
\mathrm{C} 1= & \text { plant production, plant material } \\
& \text { composted } \\
\mathrm{C} 2= & \text { plant production, plant material } \\
& \text { not composted } \\
\mathrm{D} 1= & \text { cattle farm, slurry composted } \\
\mathrm{D} 2= & \text { cattle farm, slurry }
\end{aligned}
$$

\section{Field experiment}

The experimental field was situated at Suitia $\left(60^{\circ} 11^{\prime} \mathrm{N}, 24^{\circ} 10^{\prime} \mathrm{E}\right)$ in Siuntio, about $50 \mathrm{~km}$ west of Helsinki. The experiment was started in 1982. Before that, part of the field, where two replicates were placed, had been under conventional grain production. The other part of the field, where one replicate was placed, had been under intensive sugar-beet production for several years. In 1981, the whole field was an open fallow. Due to the rainy summer of 1981 the mechanical weed control in fallow failed, and the whole experimental field was sprayed with glyphosate in the autumn.
The altitude of the field ranged from 9 to $13 \mathrm{~m}$ above sea level. The field has been drained with a tubular system since 1936. It became obvious during the study that the heterogeneity of the drainage system together with the variation in the slope of the field affected negatively certain organic cropping systems (Figs. 1 and 2). The soil type of the field was silty clay. The particle size distribution of the soil was similar for all replicates. There were detectable but insignificant differences in the initial nutrient status, $\mathrm{pH}$, and carbon content of the soil between the plots.

The experimental design of the field experiment was derived from a split-plot design with three replicates (blocks). The main factor, group of cropping systems, had two levels, conventional and organic, which were randomised within each replicate. The individual cropping systems (treatments) were further randomised within both group levels. This gives the experiment a structure, where cropping systems are nested within conventional and organic cropping. 


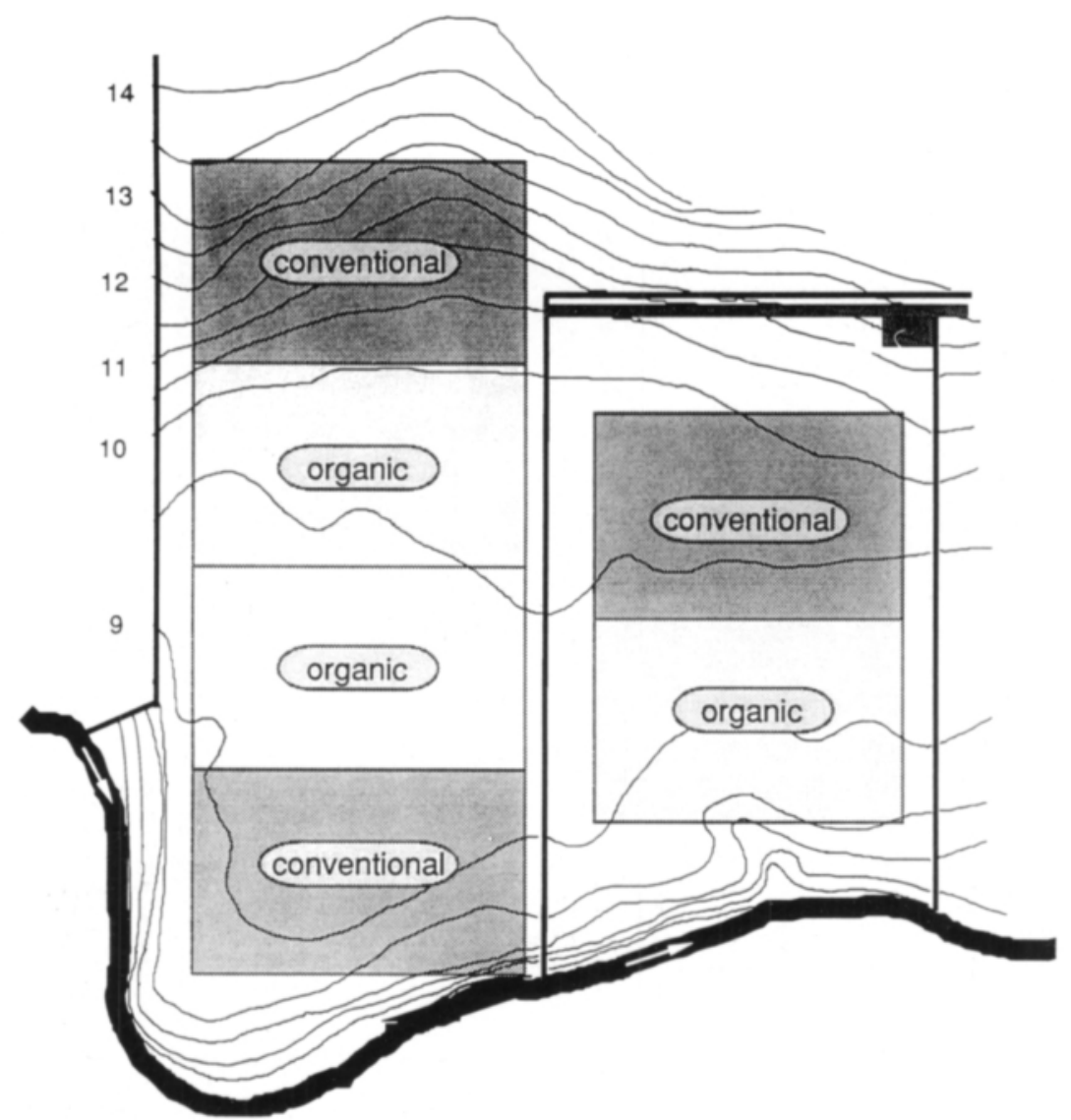

Fig. 1. Experimental field: Topographic map. The lines indicate the altitude of the field in meters above sea level.

The experimental data were analysed using SAS statistical packages. When all factors were included in the test, the ANOVA procedure for nested design was used. When a reduced number of factors were compared, appropriate modifications of ANOVA were applied. The differences between factors were further studied by using Tukey's studentized range (HSD) test. Whenever the data did not meet the requirements of the analysis of variance approach, alternative methods, discussed in separate papers in this issue, were applied.

Originally, all cropping systems were started with barley. Only one crop was to represent each cropping system yearly. The plot size was $140 \times 20 \mathrm{~m}$, and the total net area of the experiment about 6 ha. After the first year, all plots were halved to get two representative crops of each cropping system yearly. The cropping systems on half of each replicate were continued according to the original plan and designated phase $\mathrm{a}$. The crop sequences of each cropping system on the other half of the replicate, designated phase b, skipped three years. After division the plot size was $20 \times 60 \mathrm{~m}$.

The crop management practises were those adopted on actual farms in Southern Finland. Farm-scale machinery and equipment were used. Before sowing the plots were harrowed $2-3$ times with a $4 \mathrm{~m}$ wide S-string tooth harrow. Cereals were sown with a $2.5 \mathrm{~m}$ wide trailed combine drill at a row distance of $12.5 \mathrm{~cm}$, at a depth of $5 \mathrm{~cm}$. Green manuring crops and leys were sown parallelly with cereals using a $2.5 \mathrm{~m}$ wide sowing machine. Potato was planted on hills at $70 \mathrm{~cm}$ row distance, 4 seed tubers $/ \mathrm{m}$. 


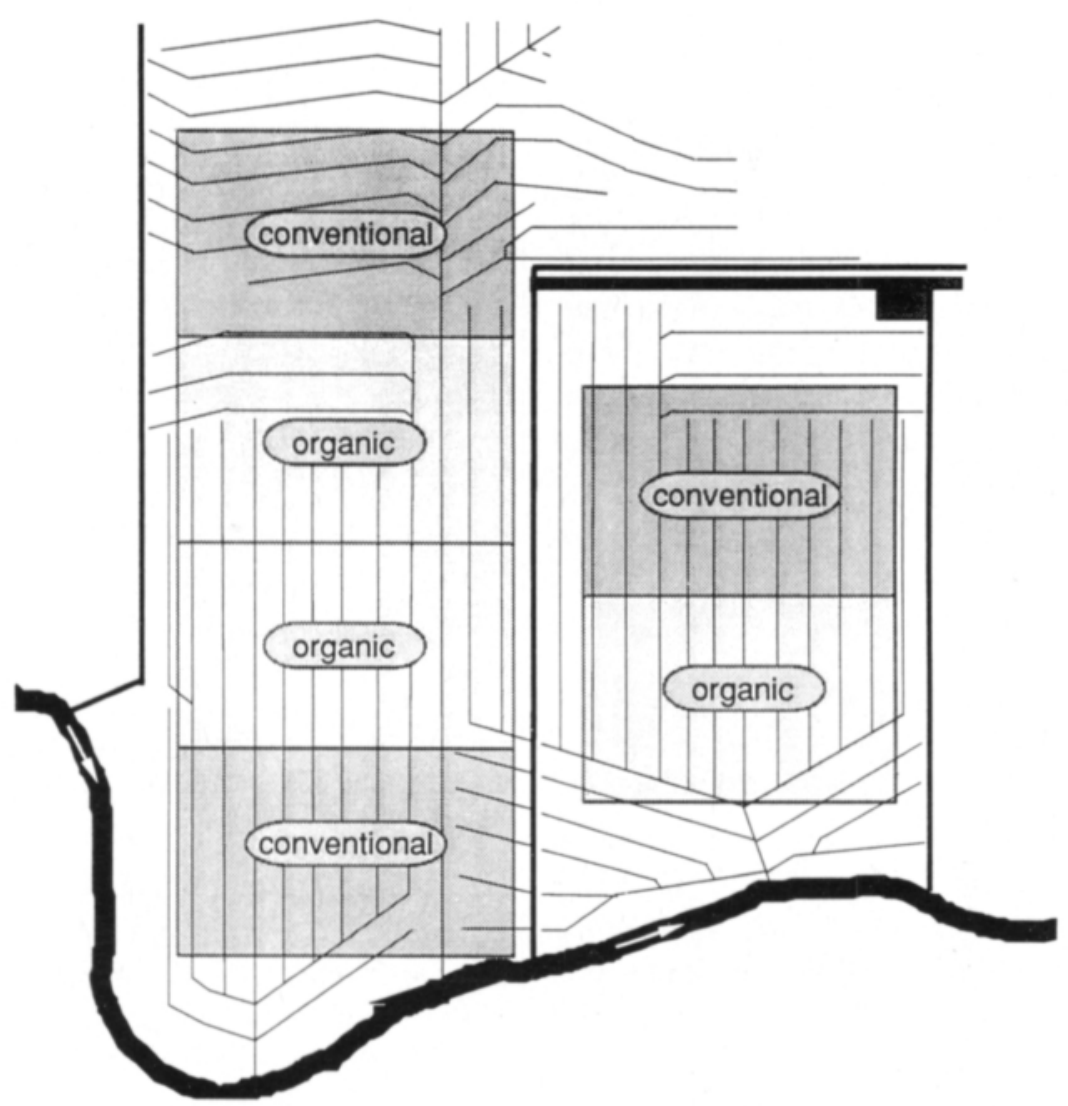

Fig. 2. Experimental field: Drainage system map. The lines indicate the arrrangement of the tubular system.

Compound fertilisers for annual crops were applied with a combined drill at a depth of $8 \mathrm{~cm}$. Leys were fertilised with a pneumatic spreading machine. The slurry was applied with an $8 \mathrm{~m}^{3}$ tank spreader and harrowed into soil thereafter. Solid organic manures were spread with a farm yard manure spreader. Pesticides were applied using a tractor spray with a working range of $10 \mathrm{~m}$.

Cereals were harvested with a $10 \mathrm{ft}$ wide combine harvester. Leys were cut with a 90 $\mathrm{cm}$ wide silage cutter. Potato was harvested with a one-row potato digger. After harvest the plots with annual crops were ploughed to the depth of $22-24 \mathrm{~cm}$.

\section{Cultivars and seed}

In all cropping systems the seed of a specific plant species was of the same origin. High quality commercial seed was used, except when seed produced on the Suitia experimental farm was available. To allow comparisons the same cultivars were grown conventionally and organically.

The barley (Hordeum vulgare L.) cultivar used throughout the experiment was 'Hankkija's Pokko', a modern, six-rowed barley. In 1988, all barley plots were divided. Half of each plot was sown with 'Pokko' according to the original plan. The other half was sown with 'Karri', an older, two-rowed barley cultivar, to compare the performance of a less intensive type of cultivar in different cropping systems. The seed rate of barley was $450-520$ germinating seeds per square metre for pure stands and barley undersown with green manuring crops. When undersown with leys 
the seed rate was reduced to $390-470$ germinating seeds per square metre.

Winter wheat (Triticum aestivum L. cv. 'Aura'), spring wheat (cv. 'Hankkija's Tapio') and oats (Avena sativa L. cv. 'Puhti') were sown at a rate of 500 germinating seeds per square metre. When oats was grown in a mixture with faba bean (Vicia faba L. cv. 'Mikko'), the seed rates for oats and faba bean were 260 and 65 germinating seeds per square metre, respectively. Turnip rape (Brassica rapa L. var. oleifera $\mathrm{cv}$. 'Emma') was sown at a rate of $10 \mathrm{~kg} / \mathrm{ha}$. The potato (Solanum tuberosum L.) cultivar used in the experiment was 'Record'.

The leys for conventional cropping consisted of grass mixtures. In 1982, a mixture of timothy (Phleum pratense L. cv. 'Tiiti', 15 $\mathrm{kg} / \mathrm{ha}$ ), meadow fescue (Festuca pratensis Huds. cv. 'Boris', $9 \mathrm{~kg} / \mathrm{ha}$ ) and perennial ryegras (Lolium perenne L. cv. 'Valinge', 6 $\mathrm{kg} / \mathrm{ha}$ ) was used. Otherwise the mixture consisted of timothy (cvs. 'Otto' and 'Kämpe II', $18 \mathrm{~kg} / \mathrm{ha}$ ) and meadow fescue (cvs. 'Bottnia II' and 'Tammisto', $12 \mathrm{~kg} / \mathrm{ha}$ ).

The leys in organic cropping were mixtures of red clover (Trifolium pratense L.) and grasses. In 1982, the mixture consisted of red clover (cv. 'Tepa', $10 \mathrm{~kg} / \mathrm{ha}$ ), timothy (cv. 'Tiiti' $15 \mathrm{~kg} / \mathrm{ha}$ ) and meadow fescue (cv. 'Boris', 5 kg/ha). In 1985, red clover (cv. 'Björn'), timothy and perennial ryegrass were sown at a rate of 9,16 , and $5 \mathrm{~kg} / \mathrm{ha}$, respectively. Due to poor overwintering of red clover the ley had to be replaced with Persian clover in 1984 and 1985, and with a green manure mixture in 1988 (see next chapter).

The green manuring and catch crop undersown with barley was subterranean clover (Trifolium subterranum cv. 'Clare'). In 1982, it was inoculated with Rhizobium sp. In 1985, subterranean clover was supplemented with white clover (Trifolium repens L. cv. 'Lena'). In 1988, a mixture of white clover (cv. 'Huia' $8 \mathrm{~kg} / \mathrm{ha}$ ) and red clover (cv. 'Bjursele' $8 \mathrm{~kg}$ / ha) was used instead of subterranean clover. In 1986, also winter wheat was undersown with a mixture of white clover, subterranean clover and Persian clover, 5, 6, and $5 \mathrm{~kg} / \mathrm{ha}$, respectively. The green manuring crop in the green fallow of 1985 was Persian clover (Trifolium resupinatum L. $10 \mathrm{~kg} / \mathrm{ha}$ ). In 1988, a mixture of oats ( $50 \mathrm{~kg} / \mathrm{ha})$, Vicia villosa (cv. 'Sam 21' 50 kg/ha), Persian clover (10 kg/ha) and Italian ryegrass (Lolium multiflorum Lam. $10 \mathrm{~kg} / \mathrm{ha}$ ) was used.

\section{Manuring}

Spring cereals, oilseed rape and potato in the conventional plant production systems received annually granular compound fertilisers. The type and the rate of fertiliser used varied according to the crop. The average yearly doses of N, P and $\mathrm{K}$ were 100, 30, and $50 \mathrm{~kg} / \mathrm{ha}$, respectively. Winter wheat was fertilised in the autumn with a N-P-K compound fertiliser at a rate of $60 \mathrm{~kg} \mathrm{~N} / \mathrm{ha}$. Additional $\mathrm{N}(80 \mathrm{~kg} / \mathrm{ha})$ was given in the spring in the form of salpeter $\left(\mathrm{NH}_{4}\right)_{2} \mathrm{NO}_{3}$.

In the conventional cattle farm, $50-80 \mathrm{~m}^{3}$ of cow slurry was applied to the annual crops. The dose of additional compound fertiliser was adjusted according to the $\mathrm{N}$ content of the slurry to keep the rate of $\mathrm{N}$ fertilisation at the same level in all conventional systems. The slurry available in the experimental farm had exceptionally low $\mathrm{N}$ and dry matter content, and its nutritional value was usually overestimated. Leys in the conventional system received $95-120 \mathrm{~kg} \mathrm{~N} / \mathrm{ha}$ for the first cut, $60-83 \mathrm{~kg} \mathrm{~N} / \mathrm{ha}$ for the second cut and $50 \mathrm{~kg}$ $\mathrm{N} /$ ha for the third cut, when the third cut was made. The third year's ley in 1985, harvested as hay, received $100 \mathrm{~kg} \mathrm{~N} / \mathrm{ha}$.

In the organic plant production system $\mathrm{C} 1$, the original idea was to harvest and to compost crop residues in the autumn and to return composted material before sowing the next crop in spring. In system $\mathrm{C} 2$, crop residues were to be ploughed into soil in the autumn. After the first two years it was obvious that the cropping system failed to produce biomass enough to be composted.

To provide manure for crops in 1984 and 1985 , composts for system $\mathrm{C} 1$ were prepared 
Table 2. Organic manures and other ingredients applied in organic cropping systems in crop sequence phases a and b in 1982-1988. For details of different types of composts see Table 3.

\begin{tabular}{|c|c|c|c|c|}
\hline \multirow[b]{3}{*}{ Year } & \multicolumn{4}{|c|}{ Organic cropping system } \\
\hline & $\mathrm{Cl}$ & $\mathrm{C} 2$ & D1 & D2 \\
\hline & \multicolumn{4}{|c|}{ Type and amount of ingredient applied/ha } \\
\hline \multicolumn{5}{|c|}{ Crop sequence phase a } \\
\hline 1982 & - & - & slurry $70 \mathrm{t}$ & slurry $70 \mathrm{t}$ \\
\hline 1983 & compost $110 \mathrm{~m}^{2}$ & - & - & - \\
\hline 1984 & compost $250 \mathrm{~m}^{3}$ & raw* compost $227 \mathrm{t}$ & - & - \\
\hline 1985 & compost $550 \mathrm{~m}^{3}$ & raw compost $553 \mathrm{~m}$ & - & - \\
\hline 1986 & - & - & compost $440 \mathrm{~m}^{3}$ & slurry $80 \mathrm{t}$ \\
\hline 1987 & compost $810 \mathrm{~m}^{3}$ & - & compost $450 \mathrm{~m}^{3}$ & slurry $50 \mathrm{t}$ \\
\hline 1988 & compost $8 \quad 16 \mathrm{t}$ & - & compost $940 \mathrm{t}$ & slurry $60 \mathrm{t}$ \\
\hline \multicolumn{5}{|c|}{ Crop sequence phase b } \\
\hline 1983 & - & - & - & - \\
\hline 1984 & compost $350 \mathrm{~m}^{3}$ & raw compost $346 \mathrm{~m}^{3}$ & compost $450 \mathrm{~m}^{3}$ & slurry $25 \mathrm{t}$ \\
\hline 1985 & compost $650 \mathrm{~m}^{3}$ & raw compost $670 \mathrm{~m}^{3}$ & compost $450 \mathrm{~m}^{3}$ & raw compost $470 \mathrm{~m}^{3}$ \\
\hline 1986 & compost $738 \mathrm{~m}^{3}$ & - & - & - \\
\hline 1987 & compost $8 \quad 10 \mathrm{~m}^{3}$ & - & - & - \\
\hline 1988 & - & & - & - \\
\hline
\end{tabular}

* raw compost $2-6=$ mixture of ingredients used in composts $2-6$

Table 3. Raw materials, N, P and K contents of the composts used in organic cropping systems in $1982-1988$.

\begin{tabular}{|c|c|c|c|c|c|c|}
\hline $\begin{array}{l}\text { Compost } \\
\text { type }\end{array}$ & $\begin{array}{l}\text { Raw materials } \\
\text { volume ratio before composting }\end{array}$ & $\begin{array}{c}\text { Total } \\
\mathrm{N}\end{array}$ & $\begin{array}{c}\text { Soluble } \\
\mathrm{N} \\
\mathrm{g} / \mathrm{kg}\end{array}$ & $\mathrm{P}$ & K & $\begin{array}{c}\text { Dry } \\
\text { matter }\end{array}$ \\
\hline Slurry & & 1.41 & 0.81 & 0.33 & 1.80 & 37.0 \\
\hline Compost 1 & clover $1 / 5$, barley straw $4 / 5$ & & & & & \\
\hline Compost 2 & clover $1 / 2$, barley straw $1 / 2$ & & & & & \\
\hline Compost 3 & peat $1 / 3$, straw $2 / 3$, urea $3 \mathrm{~kg} / \mathrm{m}^{3}$ & & & & & \\
\hline Compost 4 & peat $1 / 3$, straw $1 / 3$, slurry $1 / 3$ & 5.00 & 0.05 & 0.78 & 3.40 & 171.0 \\
\hline Compost 5 & peat $1 / 2$, straw $1 / 2$, urea $15 \mathrm{~kg} / \mathrm{m}^{3}$ & & & & & \\
\hline Compost 6 & peat $1 / 4$, straw $1 / 4$, clover $1 / 2$ & & & & & \\
\hline Compost 7 & straw, clover & 8.65 & 0.63 & 1.03 & 6.05 & 292.0 \\
\hline Compost 8 & clover & 4.80 & 0.04 & 1.32 & 3.30 & 312.0 \\
\hline Compost 9 & farm yard manure & 3.60 & 0.24 & 1.49 & 2.40 & 300.0 \\
\hline
\end{tabular}

from a mixture of clover and straw or from a mixture of peat, straw and urea. System C2 received the previous autumn before ploughing the same ingredients at quantities corresponding to the composted materials in system C1. From 1986 onwards, composts were prepared from clover or from a mixture of clover and straw for system C1. System C2 received no additional plant material from 1986 onwards (Tables 2 and 3).

The straw incorporated into the systems originated from conventional cropping on the experimental farm. The clover was harvested from leys in cropping systems D1 and D2.
In the organic systems for the cattle farm, FYM was to be applied at the rate produced by cattle, which the system theoretically could maintain. As no FYM was available, it had to be replaced by a mixture of slurry, straw and peat, which was composted in system D1. In system D2, slurry was applied at the rates used in the conventional cattle farm, without additional compound fertilisers. In 1984, a mixture of slurry, straw and peat was incorporated at an amount corresponding to that composted in system D1 (Tables 2 and 3).

The $\mathrm{N}$ content of the slurry available for the experiment was only $1.4 \mathrm{~g} / \mathrm{kg}$, the average of 
that in Finland being $3.3 \mathrm{~g} / \mathrm{kg}$ (KeMPPAINEN 1984). Due to the low dry matter content of the slurry, large quantities of straw and peat had to be added, to make the material suitable for composting. Consequently, the nutritional value of the composted material was very poor as compared to that of composted FYM.

\section{Crop protection}

In conventional cropping systems, weed control was based on the regular application of herbicides. The preparation was chosen according to crop species and to the composition of weed population to be controlled. On cereals, MCPA in mixtures with dichlorprop ('Dipro') or with dichlorprop, ionoxynil and bromoxynil ('Actril 4' and 'Actril S') were used at the recommended doses. When faba bean was grown in a mixture with oats, bentazon ('Basagran') was applied instead of MCPA containing herbicides. Potato was treated with paraquatt ('Gramoxone') before sprouting and with metribuzin ('Sencor') after sprouting. In 1987, only metribuzin was applied.

In conventional cropping, fungicides were mainly used to control seed-borne cereal diseases. Cereal seed was treated with imatsalilguatsatin ('Panoctine plus') in 1982, while methoxyethyl-mercurychloride ('Täyssato') was used in 1983-88. In the autumn of 1982, winter wheat seedlings and in the autumn of 1985 the seed were treated with thiophanatemethyl ('Topsin M') to control snow mould (Microdochium nivale). No foliar applications of fungicides were made on cereals. The seed potato was treated with thiabentazol ('Tecto') in 1987. Potato late blight (Phytophthora infestans) was controlled by two sprayings with copperoxychloride ('Kupri') in 1984 and by one spraying with methalaxyl-mancozeb ('Ridomil MZ 63 WP') following one spraying with copperoxychloride in 1987.

Insecticides were used very sparsely in conventional cropping systems. In 1976, the seed of turnip rape was pelleted with a preparation containing lindan. In 1988, cereals were pro- tected from the mass invasion of aphids by spraying once with dimethoate ('Roxion').

Virtually no pesticides were used in organic cropping systems. However, methoxyethylmercurychloride treated seed of winter wheat had to be used in 1983 and thiabendazole treated seed potato in 1987, when no untreated seed was available. Potato was sprayed with copperoxychloride once in 1984 and twice in 1987 to control late blight.

In organic cropping no weed control was attempted for cereals. Potato was earthed up twice in 1984 and once in 1987. In 1984, thistle (Cirsium arvense L.) was weeded manually, which took approximately 28 hours/ha. The weeds in annual clover in 1984 were harrowed with a weed harrow with no success. The next year the weeds were cut twice at the height of clover canopy.

\section{Weather}

The climate of Suitia is typical of the coastal areas of Southern Finland. It is north temperate and semi-continental. The average length of growing season is 170 days and the effective temperature sum (over $+5^{\circ} \mathrm{C}$ ) is 1250. The characteristic climatic risk factors are June draughts and wet periods at harvest (Mukula and Rantanen 1987).

The numerical weather data from Porla weather station, $10 \mathrm{~km} \mathrm{NW}$ of Suitia, shows that the average daily temperature and rainfall in 1981-1988 did not differ from the long-term means. However, there was great yearly variation in the thickness and duration of the snow cover, temperatures and rainfall (Fig. 3). Summer frosts occurred in 1982 and 1983. Draught affected the crop growth in 1986 and especially in 1988 . The wet weather caused problems with harvesting in 1984, 1986 and 1987.

\section{Summaries of the results}

\section{Crop yields}

Thed average yield of barley in organic cropping varied between a quarter and half of 


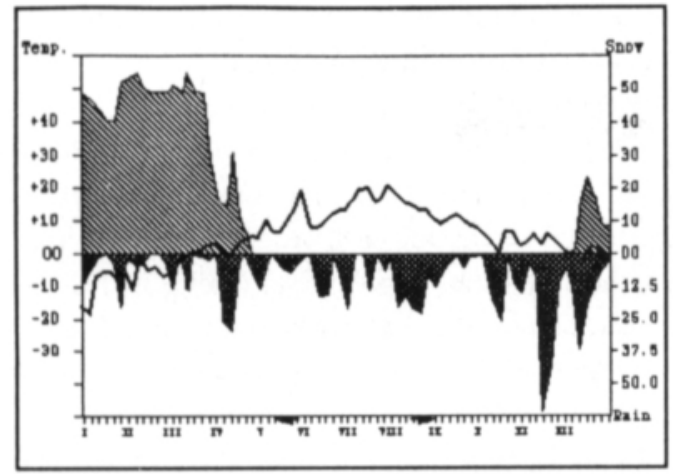

1982

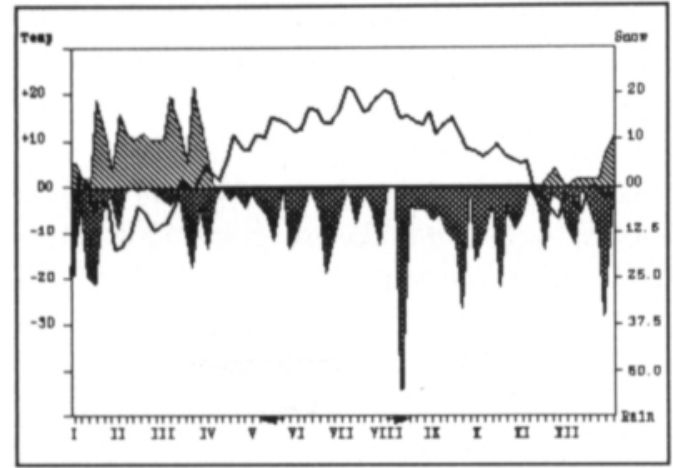

1983

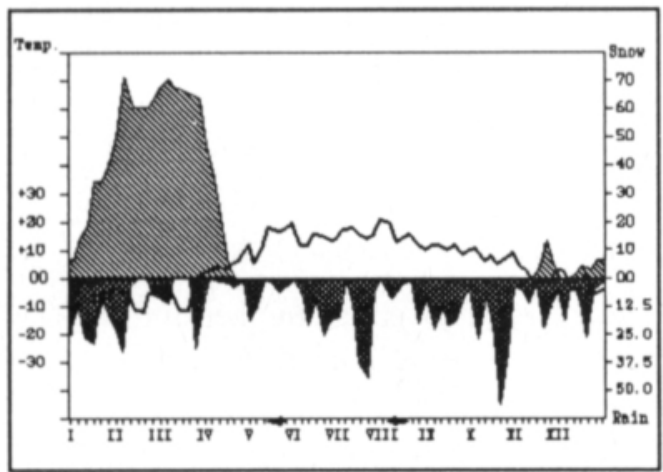

1984

Fig. 3. Annual weather data. Mean temperature, snow depth, rainfall and the growing period of barley (cultivar Pokko).

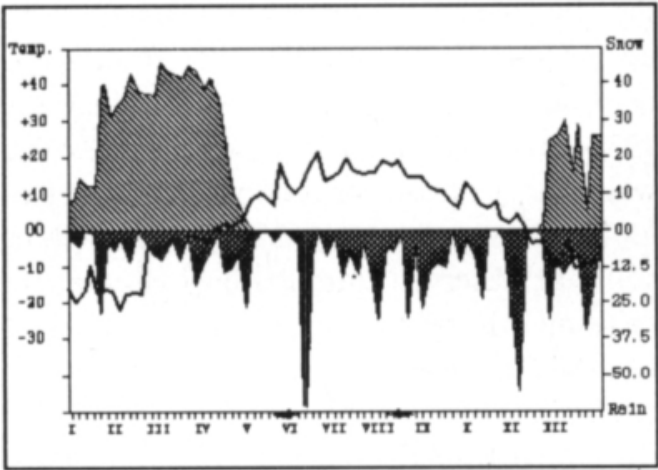

1985

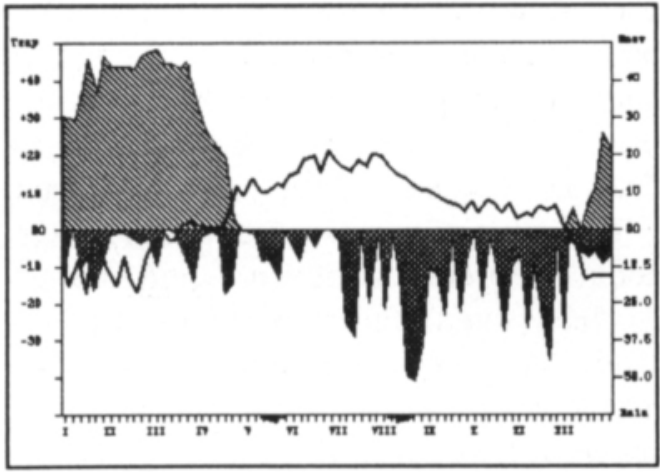

1986

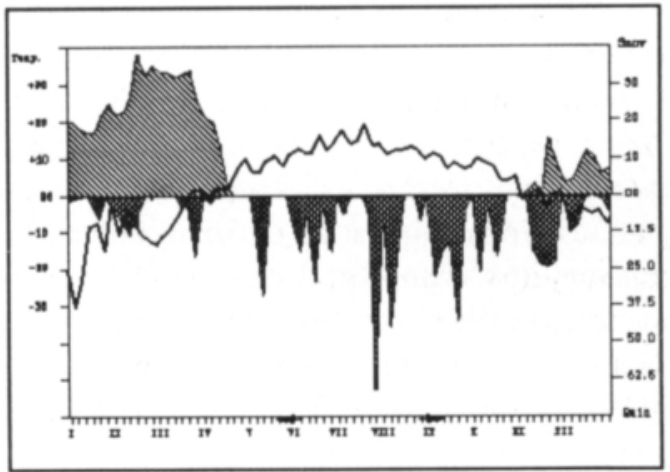

1987

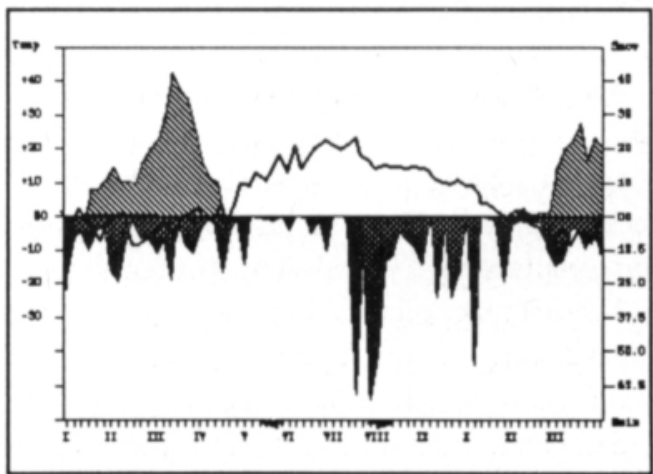

1988 
that in conventional cropping. The relative difference in yields between conventional and organic cropping was greatest in 1985 and 1988 when a comparatively low yield, $3 \mathrm{t} / \mathrm{ha}$, was obtained from conventionally grown barley. The severe lack of $\mathrm{N}$ in organic cropping could be observed from the beginning of the growing season. In 1983 and 1986, the absolute yield of barley in the organic cropping system was $3 \mathrm{t} / \mathrm{ha}$, while $6 \mathrm{t} / \mathrm{ha}$ was obtained in the conventional systems.

In 1988, two cultivars of barley were compared in all cropping systems. In organic cropping the cultivar 'Hankkija's Pokko' yielded only two-thirds of the yield of the cultivar 'Karri'. In conventional cropping the yield difference between cultivars was insignificant.

The yields of winter wheat and oats were about $40 \%$ of those obtained conventionally. There was a similar proportion in potato yields. The clover-grass leys yielded well in the first year after sowing, producing a yield of good quality and quantity. The ley outwintered later because of the water and ice cover on the flat fields.

The differences in crop yield between individual organic systems under the same crop were insignificant. Compost treatments did not increase yields as compared to green manuring with almost no nutrients added. In conventional cropping, increasing diversity in crop sequence in general increased the yields of barley and winter wheat (KORVA and VARIS 1990).

\section{Soil fertility and biological activity}

Changes in the chemical properties of soil in 1982-1988 were insignificant. The initial concentration of soluble $\mathrm{P}, \mathrm{K}, \mathrm{Ca}, \mathrm{Mg}, \mathrm{B}$, $\mathrm{Mn}, \mathrm{Cu}$ and $\mathrm{Zn}$ remained practically unchanged during the experiment. The major fertility problem in organic cropping was the obvious lack of $\mathrm{N}$ available to plants.

The compaction of soil increased during the experiment. It could be observed visually and manifested as difficulties in ploughing. The negative effects were most pronounced in organic cropping systems where the poor soil structure apparently accelerated the outwintering of clover and increased $\mathrm{N}$ losses via denitrification under wet conditions.

The microbial activity of soil measured as nitrification potential, dehydrogenase activity, cellulolytic activity, and respiration was studied by HeINONEN-TANSKI (1990) in 19831988. The leys, when not destroyed, activated the microbes of the soil; otherwise there were few significant differences between the cropping systems.

The occurrence of earthworms was studied by NUUTINEN and HAUKKA (1990) by sampling with formalin and by taking soil-cores. Most of the individuals were Aporrectodea caliginosa (Sav.), the rest of the individuals identified being representatives of the Lumbricus species. L. terrestris (L.), a very beneficial species, occurred rarely in the plots. In 1988, the average number and the total dry weight of earthworms in different cropping systems varied from 23 to $92 / \mathrm{m}^{2}$ and from 1.0 to 3.2 $\mathrm{g} / \mathrm{m}^{2}$, respectively. No statistically significant differences were found between the cropping systems. The differences in the patterns of earthworm abuncance in the three replicates were related to the local waterlogging and compaction of the experimental field.

\section{Weeds, plant diseases and insect pests}

In 1988, the average number and the DM yield of the weeds in barley in organic cropping were $6-7$-fold those in conventional cropping. Observations in the field suggest that weeds had very little effect on crop growth, they merely filled the space left empty due to poor growth of the crop. The winter wheat in the cropping sequence effectively suppressed the weeds, whereas the spring cereals and the outwintered clover leys favoured them (KAUPPILA 1990).

Powdery mildew, yellow rust, and Septoria leaf blotch in winter wheat, occurred more commonly in conventional cropping, while root and foot rot diseases (Bipolaris sorokiniana, Gaeumannomyces graminis and $\mathrm{Fu}$ sarium spp.) were more common in organic 
cropping. The plant pathogens were not a major factor limiting yields in organic farming (HannukKala and Tapio 1990).

The occurrence of insects was studied by Helenius (1990). In 1988, the densities of the aphid Rhopalosiphum padi L. were four times higher and the densities of the Frankliniella tenuicornis Uzel were $50 \%$ lower in conventional cropping than in organic cropping. The catch rate of Bembidion spp. (col., Carabidae) in the conventional systems was one quarter of that of the organic ones. The densities of Coccinella septempunctata L. (col., Coccinellidae) in conventionally grown barley were almost three times those of organically grown barley. This was attributed to the higher aphid densities. Crop stand characteristics were the main reason for the differences in populations between conventional and organic cropping.

\section{Discussion}

Several studies report lower yields for organic cropping as compared to conventional cropping. The relative difference in yields between conventional and organic cropping has frequently been smaller than in the present study (Dlouhy 1981, Lockeretz et al. 1981, Pettersson 1982). However the relative yield difference between systems varied considerably from year to year. This was also the case in the studies of SIPPOLA (1983) and RINNE et al. (1987). The absolute yields obtained in organic cropping were similar to those recorded by MELA (1988) on organically cultivated farms in Finland.

The primary reason for poor crop growth in organic cropping was apparently the acute $\mathrm{N}$ deficiency. The expected level of $\mathrm{N}$ available to plants was never reached due to the poor performance of clover undersown with cereals, the low $\mathrm{N}$ content of the slurry available, the low $\mathrm{N}$ content of the composted plant material and to the failure to replace outwintered clover leys with annual clover.

The conversion from conventional to organic cropping usually causes complications until the nutritional and microbiological bal- ance is reached in the organic system. Normally this takes 2-4 years (Dloury 1981). In the present study, no obvious recovery of organic systems was detected during the 7 year period.

During the first years of conversion the poor growth together with heavy machinery used in composting resulted in soil compaction. The root development of the following crop was probably suppressed, which made the soil structure more vulnerable to compaction. The disturbed soil structure increased the risk of occasional cover of water and ice on the flat field, which was further promoted by the topography of the field and heterogeneity of the drainage system. All these disadvantages resulted in the poor overwintering of clover and the reduced microbial activity of soil. In addition, much of the initially low $\mathrm{N}$ content in soil was apparently lost due to denitrification in anaerobic conditions.

The organic cropping systems in the present study may be criticised for not being representative of those adopted on actual organically cultivated farms. However, it seems justified to conclude that unexpected difficulties will occur especially on clay soil during the conversion period. Even the small differences in field topography may cause problems not detected in conventional cropping, a fact that has been emphasized also by BEsson et al. (1978).

The study clearly showed that much more experience and know-how of the soil and crop behaviour in local conditions is needed in running an organic cropping system succesfully than in running a conventional one. Many of the obvious mistakes made in organic cropping during the experiment resulted from the fact that the general methodology of such systems is poorly studied and developed. Apparently many farmers converting from conventional to organic cropping are facing similar problems. It is therefore important that future studies on organic agriculture aim at improving the methods.

Acknowledgements. We are greatly indebted to the study team for valuable suggestions in preparing the man- 
uscript. In fact, the list of authors could be much longer than it is. We wish, to thank Esa Palmujoki and Heikki Ojala for taking care of the practical aspects of the experiment. Thanks are due to Seppo Karttunen, Hannu Konkka and the personnel of the Suitia Research Farm for technical assistance. We also wish to thank the staff of at the Agricultural Research Centre for soil and compost analyses, as well as the summer assistants, Tapani Pulkki, Tove Unnèrus and Andy Karjus, for excellent work.

\section{References}

Besson J.-M., Vogtmann H., Lehmann V. \& AugstBURger F. 1978. DOK: Versuchsplan und erste Ergebnisse eines Projektes zum Vergleich von drei verschiedenen Anbaumethoden. Summary: DOC: Design and first results of an experiment concerned with 3 contrasting systems of husbandry. Schweitzerische landwirtschaftliche Forschung 17 (3): 191-209.

Dıoury, J. 1981. Alternativa odlingsformer - växtprodukters kvalitet vid konventionell och biodynamisk odling. Inst. växtodling, Sveriges lantbruksuniversitet. Rapport 91:.

Hannukkala, A.O. \& Tapio, E. 1990. Conventional and organic cropping systems at Suitia V: Cereal diseases. J. Sci. Agric. Soc. Finl. 62:.

HeINONEN-TANSKI, H. 1990. Conventional and organic cropping systems at Suitia III: Microbial activity in soils. J. Sci. Agric. Soc. Finl. 62:.

Helenius, J. 1990. Conventional and organic cropping systems at Suitia VI: Insect populations in barley. J. Sci. Agric. Soc. Finl. 62:.

KaupPILA, R. 1983. Koetuloksia Suomessa uusista palkokasvilajeista ja -lajikkeista. Abstract: Results from experiments with new cultivars and species of legumes in Finland. Suomen itsenäisyyden juhlavuoden 1967 rahasto. Biologisen typensidonnan ja ravinnetypen hyväksikäytön projekti. 6: 51-92.

KaUPPILA, R. 1990. Conventional and organic cropping systems at Suitia IV: Weeds. J. Sci. Agric. Soc. Finl. 62:.

Kemppainen, E. 1984. Karjanlannan ravinnepitoisuus ja syyt sen vaihteluun. Abstract: The nutrient content of livestock manure and the causes of its variation. Suomen itsenäisyyden juhlavuoden 1967 rahasto. Bio- logisen typensidonnan ja ravinnetypen hyvăksikäytön projekti (SITRA Nitrogen project). 11: 1-80.

Korva, J. \& VARIS, E. 1990. Conventional and organic cropping systems at Suitia II: Crop growth and yields. J. Sci. Agric. Soc. Finl. 62:

Lockeretz, W., Shearer, G. \& Kohl, D. 1981. Organic farming in the corn belt. Science 211: 540-547.

Mela, T. 1988. Luonnonmukainen peltoviljely Suomessa. Viljelymenetelmät, rikkakasvit, peltojen viljavuus, sadot ja sadon laatu. Summary: Organic farming in Finland. Cultivation methods, weeds, soil fertility, yields, and yield quality. Helsingin Yliopiston kasvinviljelytieteen laitos. Julkaisuja 16: 1-220.

Munula, J. \& Rantanen, O. 1987. Climatic risks to the yield and quality of field crops in Finland. I. Basic facts about Finnish field crops production. Ann. Agric. Fenn. 26: 1-18.

NUUtinen, V. \& HAUKKA, J. 1990. Conventional and organic cropping systems at Suitia VII: Earthworms. J. Sci. Agric. Soc. Finl. 62:.

Pettersson, B.D. 1982. Konventionell och biodynamisk odling, jämförande försök mellan två odlingssystem 1971-1979. Nordisk forskningsring, Meddelande 32: $1-119$.

Rinne, S.-L., Simojokı, P., Sippola, J. \& Rinne, K. 1987. Omavaraisessa viljelyssä suuret satovaihtelut. Koetoim. ja Käyt. 44: 33.

Sippola, J. 1983. Research project: Possibilities of food production in Finland without imported energy inputs. Swedish Univ. Agr. Sci., Inst. växtodling, Rapport 124: 89-91.

Ms received January 13, 1991 


\section{Suitian viljelyjärjestelmät I: Koejärjestely ja yhteenveto}

\author{
Hannukkala, A.O. ${ }^{1}$, Korva, J. ${ }^{2}$ ja Tapio, E. ${ }^{3}$ \\ 1 MTTK, Kasvinsuojelun tutkimuslaitos \\ ${ }^{2}$ Helsingin yliopiston Kasvinviljelytieteen laitos \\ ${ }^{3}$ Helsingin yliopiston Kasvipatologian laitos
}

Tavanomaisen ja luonnonmukaisen viljelyn vaikutusta viljelykasvien sadon maaăraăn ja laatuun, maaperăn kemiallisiin ja biologisiin ominaisuuksiin sekä rikkakasvien, kasvitautien ja tuhoeläinten esiintymiseen tutkittiin Suitian koetilalla Siuntiossa järjestetyssä kenttăkokeessa vuosina 1982-88. Koe koostui neljästä tavanomaisesta ja neljästă luonnonmukaista viljelyă kuvaavasta viljelyjärjestelmästä.

Tavanomaista kasvintuotantoa edusti kolme viljelyjärjestelmää: Ohran monokulttuuriviljely (A1), eri viljalajeista muodostettu viljelykierto (A2) ja monipuolinen viljelykierto, jossa viljojen ohella viljeltiin perunaa ja rypsiă (A3). Tavanomaista nautakarjatuotantoa kuvaavan viljelyjärjestelmän (B) viljelykiertoon sisältyi kolmivuotinen heinänurmi sekä viljakasveja.

Tavanomaisessa viljelyssă lannoitus perustui văkilannoitteisiin, joita käytettiin viljavuustutkimuksen perusteella kunkin viljelykasvin tarpeen mukaan. Karjatilan viljelyjärjestelmässă kăytettiin lisăksi lietelantaa, jolloin väkilannoitemääriă vastaavasti alennettiin. Kemiallisia torjunta-aineita käytettiin säännőllisesti rikkakasvien torjuntaan sekä viljojen kylvösiemenen peittaukseen. Perunaa viljeltäessä perunarutto torjuttiin kemiallisesti. Vuonna 1988 kirvat torjuttiin kemiallisesti viljakasvustoista.

Luonnonmukaista viljelyă edusti kaksi kasvintuotantotilalle ja kaksi nautakarjantuotantotilalle soveltuvaa viljelyjärjestelmää. Luonnonmukaisessa viljelyssä ei käytetty văkilannoitteita eikă kemiallisia torjunta-aineita.

Kasvintuotantotilan viljelykiertoihin ( $\mathrm{C} 1$ ja $\mathrm{C} 2$ ) sisältyi neljänă vuotena vilja, yhtenă peruna yhtenă viherkesanto. Viljojen typensaanti pyrittiin turvaamaan typpeä sitovien aluskasvien avulla. Lisăksi lannoitteena käytettiin olkisilppua, turvetta ja apilan vihermassaa. Järjestelmässä C1 kaikki lannoitukseen käytetty orgaaninen aines kompostoitiin ennen käyttöä. Järjestelmässă C2 orgaaniset lannoitteet levitettiin maahan kompostoimattomina.

Luonnonmukaisen karjatilan (D1 ja D2) viljelykierroissa kolmivuotista apila-heinänurmea seurasi 3 viljanviljelyvuotta. Lannoitukseen kảytettiin lietelantaa, joka järjestelmässă D1 imeytettiin turve-olkisilppuun ja kompostoitiin. Järjestelmăssả D2 vastaavat aineet levitettiin kompostoimattomina peltoon.

Ohran keskimäăräinen sato luonnonmukaisessa vilje- lyssä oli hyvinä satovuosina noin puolet ja huonoina satovuosina noin neljännes tavanomaisen viljelyn sadosta. Syysvehnä, kaura ja peruna tuottivat luonnonmukaisessa viljelyssă noin $40 \%$ tavanomaisen viljelyn sadosta. Ensimmäisenă satovuonna luonnonmukaisesti viljelty apilanurmi tuotti samansuuruisen sadon kuin tavanomainen heinănurmi. Heikon talvehtimisen vuoksi apilanurmet jouduttiin toisena ja kolmantena vuonna korvaamaan yksivuotisella apilalla, joka tuotti erittäin alhaisen sadon tavanomaisesti viljeltyihin nurmiin verrattuna.

Viljelykasvien heikko menestyminen luonnonmukaisissa viljelyjärjestelmissä oli ensisijaisesti seurausta akuutista typenpuutteesta etenkin kasvukauden alussa. Typenpuute aiheutui palkokasvien odotettua heikommasta menestymisestä ja orgaanisten lannoitteiden alhaisesta typpipitoisuudesta. Lisäksi osa typestä menetettiin talven aikana veden ja jään alla vallitsevissa hapettomissa olosuhteissa.

Kasvien heikko kasvu luonnonmukaisessa viljelyssä johti myös maan tiivistymisongelmiin. Tiivistyneessä maassa kasvit kasvoivat entistä huonommin. Heikosti vettä läpäisevässă maassa talvehtivat kasvit joutuivat alttiiksi jääpoltteelle. Koekentän korkeuserot ja salaojitusjärjestelmän puutteet vaikuttivat erityisesti luonnonmukaisten viljelyjärjestelmien kasvien talvehtimiseen ja kasvuun. Vastaavia ongelmia ei oltu havaittu koetta edeltävinä vuosina, jolloin alue oli tavanomaisessa viljelyssä.

Rikkakasvit eivät aiheuttaneet sanottavia ongelmia tutkimusjakson aikana. Rikat näyttivăt valtaavan tyhjiksi jaăneet kasvupaikat eivätkä kilpailleet merkittävăsti viljelykasvien kanssa. Kasvitautien ja tuholaisten osuus satotappioiden aiheuttajana oli văhäinen. Maan biologisessa aktiivisuudessa ja lierojen esiintymisessä ei todettu eroja tavanomaisen ja luonnonmukaisen viljelyn välillă. Sekă tavanomaiset että luonnonmukaiset nurmet aktivoivat maan pieneliötoimintaa.

Tutkimus osoitti, ettă menestyksellinen luonnonmukaisen viljelyn toteuttaminen edellyttää hyvin paljon kokemusta ja tietoa viljeltävän pellon ominaisuuksista. Etenkin savimailla luonnonmukaiseen viljelyyn siirryttăessă maan viljavuuden ylläpito siirtymävaiheessa saattaa tuottaa ongelmia. Luonnonmukaista viljelyä koskevissa tutkimuksissa tulisi jatkossa pyrkiä kehittämään viljelymenetelmäă ja ratkaisemaan viljelyn ongelmakohtia. 